УДК 373.31

Олена Сокуренко,

ORCID iD 0000-0003-1702-4802

кандидат педагогічних наук, доиент, завідувач кафедри теорії й методики

дошкільної та початкової освіти

Миколаӥвський обласний інститут

післядипломної педагогічної освіти

вул. Адміральська, 4-а, 54001, м. Миколаїв, Україна

olena.sokurenko@moippo.mk.ua

Оксана Рибачук, ORCID iD 0000-0003-1286-3471

методист кафедри теорії й методики дочкільної та початкової освіти

Миколаївський обласний інститут післядипломної педагогічної освіти вул. Адміральська, 4-а, 54001, м. Миколаїв, Україна oksana.rybachuk@moippo.mk.ua

\title{
АПРОБАЦІЯ МОДЕЛЕЙ УПРОВАДЖЕННЯ ІНТЕГРОВАНОГО НАВЧАННЯ В ПОЧАТКОВІЙ ШКОЛІ: ЗДОБУТКИ ДОСЛІДНО-ЕКСПЕРИМЕНТАЛЬНОӤ РОБОТИ РЕГІОНАЛЬНОГО РІВНЯ
}

У Концепції «Нова українська школа» визначено стратегічні завдання реформування системи освіти України. Це зумовлюе доиільність реалізації компетентнісного підходу в початковій школі засобами інтеграції змісту освіти й форм організації освітнього процесу. Такий підхід потребує дослідження регіональних особливостей організації освітнього процесу в початковій школі. У статті представлено результати дослідно-експериментальної роботи регіонального рівня за темою «Упровадження технологіі інтегрованого навчання в початковій школі на засадах ідей та положень Нової української школи» на базі Миколаївського обласного інституту післядипломної педагогічної освіти (МОІППО) та закладів освіти області, яку проводить кафедра теорії й методики дошкільної та початкової освіти МОІППО. Така діяльність спрямовується на розроблення та апробачію моделей упровадження інтегрованого навчання молодших школярів на засадах ідей та положень Нової української школи для різних типів закладів освіти, у яких є школа І ступеня.

Ключові слова: інтеграція; інтегроване навчання; компетентнісний підхід; міжпредметні компетентності; моделі інтегрованого навчання; нова украӥнська школа; освітній прочес; початкова школа.

(C) Рибачук О. А., Сокуренко О. О., 2021

Постановка проблеми в загальному вигляді та ії зв'язок із важливими науковими і практичними завданнями. Актуальність і доцільність використання міжпредметної інтеграції підтверджується положеннями Державного стандарту по- чаткової освіти, які передбачають організацію освітнього процесу в початковій школі із застосуванням діяльнісного підходу на інтегрованій основі.

В умовах сьогодення досягти мету якісної початкової освіти стає можливим 
завдяки реалізації ідеї інтеграції, яка $\epsilon$ значним здобутком дидактики.

Саме інтеграція змісту освіти, що передбачає поєднання в одному предметі елементів різних навчальних предметів (курсів або тем), є підгрунтям формування цілісної картини світу, наукового світогляду молодших школярів. Завдяки інтеграції в свідомості дитини створюється цілісне уявлення про об'єкт, що вивчається, формуються міжпредметні компетентності та вирішуються основні суперечності освіти - протиріччя між безмежністю знань i обмеженими людськими ресурсами, як слушно зауважує Л. Т. Ніколенко (Ніколенко Л. Т., 2018, с. 6).

На думку Н. Б. Бібік, створення інтегрованого освітнього простору в умовах нової української школи $є$ важливим ресурсом упровадження компетентнісного підходу, і як прогнозований результат - підвищення ефективності освітнього процесу в початковій школі, формування ключової компетентності «уміння навчатися впродовж життя».

Особливої актуальності набувають ідеї інтеграції різнопредметних знань в освітньому процесі початкової школи, оскільки молодшим школярам властиве цілісне сприйняття об'єктів та явищ навколишнього світу. Послідовність етапів реалізації міжпредметної інтеграції змісту початкової освіти передбачає застосування міжпредметних зв'язків на уроках суміжних дисциплін на основі репродуктивної діяльності та елементів проблемності, формування міжпредметних навчальних проблем і самостійний пошук учнями шляхів їх розв'язання, організацію систематичного проблемного навчання на основі вирішення ускладнених міжпредметних проблем усередині інтегрованого курсу.

Аналіз основних досліджень і публікацій із зазначеної проблеми. У процесі формування цілісної картини світу та наукового світогляду, що грунтується на продуктивному засвоєнні здобувачем освіти знань, і його інтелектуального розвитку, важливе значення має встановлення широких зв'язків як між різними розділами навчального курсу, так і між різними дисциплінами в цілому.

Особливої актуальності набули спроби інтеграції різнопредметних знань у початковій ланці освіти, оскільки молодші школярі сприймають об'єкти навколишнього світу цілісно, не усвідомлюючи їхніх істотних ознак (Мариновська О. Я., 2011, c. 4 ).

Сучасні наукові дослідження теоретико-методологічних засад організації освітнього процесу в початковій школі дають підстави стверджувати, що розв'язання проблеми особистісно орієнтованої освіти та іiі продуктивності пов'язане 3 інтеграцією змісту освіти, створює умови для зміцнення та збереження психічного і фізичного здоров'я школярів.

Отже, виокремимо переваги інтегрованого навчання: краще засвоєння змісту навчальних предметів у різних контекстах; глибше розуміння будь-якої теми завдяки іiі дослідженню через різноманітну проблематику навколишнього середовища; краще усвідомлення комплексного підходу; удосконалення навичок системного мислення. Освітній процес має бути орієнтований на набування здобувачами освіти навчальних та життєвих компетентностей і передбачати перехід від екстенсивно-інформативного типу навчання до відкритого, незалежного, інтегрованого навчання (Письменна I. I., 2019, с. 173).

Проведений аналіз наукових і методичних джерел свідчить про значущість і важливість інтеграції змісту освіти, на чому наголошували прогресивні педагоги всіх часів. Так, дидактичні особливості інтеграції змісту навчання на сучасному етапі розвитку освіти досліджували вчені Н. Б. Бібік, Л. С. Виготський, В. В. Давидов, М. С. Вашуленко, В. П. Тименко, С. І. Якименко, О. Я. Савченко та інші.

Теоретичну основу дослідження питання упровадження інтеграції в освітній процес початкової школи станов- 
лять концептуальні ідеї гуманістичної парадигми освіти (Г. О. Балл, Є. С. Барбіна, С. У. Гончаренко, І. А. Зязюн, Г. С. Костюк, А. Г. Маслоу, В. О. Сухомлинський, А. Сущенко та інші); закономірності формування особистості та розвитку дитини молодшого шкільного віку (І. Д. Бех, Д. Б. Ельконін, О. В. Запорожець, Я. Л. Коломінський та ін.); ідеї використання міжпредметних зв'язків та предметно-інтегрованого навчання (М. Р. Арцишевська, Н. Б. Бібік, М. С. Вашуленко, В. В. Ільченко, Л. А. Кочина, О. Я. Савченко, С. І. Якименко та інші).

Упровадження інтеграції дає можливість формувати в учнів якісно нові знання, що характеризуються значно вищим рівнем пізнавальних процесів, мислення, здатністю їхнього застосування в нових ситуаціях.

На думку Н. Костюка, «інтеграція це процес взаємодії елементів із заданими властивостями, що супроводжується встановленням, ускладненням i зміцненням істотних зв'язків між цими елементами на основі достатньої підстави, в результаті якої формується інтегрований об'єкт (цілісна система) 3 якісно новими властивостями, у структурі якого зберігаються індивідуальні властивості вихідних елементів». Інтеграція дозволяє організувати освітній процес таким чином, щоб учні не лише могли знаходити інформацію, а й опрацьовувати її різними способами та використовувати (Інтегроване навчання: тематичний і діяльнісний підхід (електронний ресурс), 2017).

На інтегрованих уроках доцільним $\epsilon$ впровадження проєктної, командної та групової діяльності, організація досліджень. Перевагами інтегрованого навчання є висока пізнавальна активність школярів, міцне засвоєння знань, набуття учнями досвіду навчально-творчої діяльності.

Інтегрований освітній процес у початковій школі грунтується на принципах доступності, науковості, послідовності, системності, цілісності, логічності, верти- кального тематизму.

Можливі різні форми інтеграції знань, a came:

- контент-орієнтована інтеграція навчальних предметів, що реалізується у формі тематичного навчання. Це навчання на основі об’єднання навколо однієї теми знань із різних навчальних дисциплін. Тематичний підхід передбачає організацію освітнього процесу на основі однієї «змістової одиниці» - теми. Темою може бути певне поняття, цілісний розгляд якого зумовлює формування загальних уявлень про систему, до складу якої входить це поняття як елемент. Тема може формулюватися вчителем у вигляді запитання чи опису проблеми, під час вирішення яких учні опановують зміст навчальної програми;

- інтеграція, орієнтована на формування способів дій (або інтеграція навичок). Діяльнісний підхід реалізується з використанням однакових способів дій на уроках із різних навчальних дисциплін чи через організацію інтегрованої діяльності на інтегрованих уроках або впродовж навчального дня без визначення меж уроків. Учні вчаться критично мислити, створювати моделі, вирішувати проблеми, оцінювати ризики. Діяльнісний підхід передбачає організацію освітнього процесу на основі організаційно-методичної системи щоденної діяльності учнів та «стратегій» розвитку критичного мислення в рамках тематичного чи предметного навчання (Інтегроване навчання - Глосарій. Онлайн-курс для вчителів початкових класів, 2017).

У початковій школі міжпредметна інтеграція реалізується через створення інтегрованих курсів, виконання навчальних проєктів; організацію тематичних днів і тижнів; проведення інтегрованих, бінар- 
них уроків.

Інтеграція навчального матеріалу 3 різних навчальних предметів здебільшого відбувається навколо певного явища, процесу довкілля для розв'язання проблеми міжпредметного характеру або створення творчого продукту. Наскрізна тема має бути цікавою для учнів. Вона є основою інтеграції змісту і дозволяє реалізувати принципи педагогіки партнерства.

Тематичне навчання формує в молодших школярів цілісну картину світу, здатність сприймати предмети і явища різнобічно, системно, емоційно, сприяє поглибленню та розширенню знань, їхньому практичному застосуванню.

Підготовка до проведення тематичних днів і тижнів в освітньому процесі початкової школи передбачає такі підготовчі кроки:

1) зіставлення матеріалу навчальних програм і предметів для виявлення можливих варіантів інтеграції;

2) вибір тем з урахуванням їхньої доцільності й інформативності, пізнавальних інтересів учнів;

3) визначення мети та обов'язкових результатів навчання;

4) вибір форм і методів реалізації навчального матеріалу;

5) добір дидактичних матеріалів;

6) конструювання уроку, розподіл часу (Інтегроване навчання: тематичний і діяльнісний підхід (електронний ресурс), 2017).

Під час планування тематичного дня вчитель може створити інтелект-карту (ментальну карту, карту пам'яті, діаграму зв'язків) як метод структурування концепцій із використанням графічного запису.

Окреслення невирішених питань, порушених у статті. Відповідно до Концепції «Нова українська школа» реалізація стратегічних завдань реформування змісту освіти зумовлює доцільність компетентнісного підходу в початковій школі засобами інтеграції змісту освіти. Актуальність використання міжпредметної інтеграції під- тверджується положеннями Державного стандарту початкової освіти, який передбачає організацію освітнього процесу із застосуванням діяльнісного підходу на інтегрованій основі.

У процесі реалізації інтегрованого підходу навчальний матеріал доповнюється та повторюється іншими напрямами, що значно покращує результат порівняно 3 традиційним вивченням предметів. Інтегрований підхід сприяє систематизації знань, розвиває здатність переносити їх в інші галузі, уможливлює формування наукового світогляду, створення в учнів цілісного уявлення про досліджуваний об'єкт, оскільки молодшим школярам властиве цілісне сприйняття об'єктів навколишнього світу (Інтегроване навчання: тематичний $\mathrm{i}$ діяльнісний підхід (електронний ресурс), 2017).

Тож необхідність модернізації змісту початкової освіти, визначення теоретико-методологічних засад організації освітнього процесу в початковій школі на засадах міжпредметної інтеграції зумовлює доцільність виконання програми дослідно-експериментальної роботи регіонального рівня.

Формулювання мети i завдань статті. Упровадження інтегрованого підходу в освітній процес початкової школи дає можливість формувати в учнів якісно нові знання, що характеризуються значно вищим рівнем пізнавальних процесів, мислення, здатністю їх застосування в нових ситуаціях. Саме тому дослідно-експериментальна робота регіонального рівня за темою «Упровадження технології інтегрованого навчання в початковій школі на засадах ідей та положень Нової української школи» на базі МОІППО та закладів освіти області спрямована на реалізацію нового змісту освіти, дослідження особливостей, розроблення та апробацію моделей інтегрованого навчання молодших школярів у закладах загальної середньої освіти різних типів.

Метою статті є висвітлення особли- 
востей добору змісту початкової освіти на засадах міжпредметної інтеграції і практичної спрямованості, моделей упровадження інтегрованого навчання в початковій школі, що визначено в рамках дослідно-експериментальної роботи регіонального рівня.

Завдання статті:

1. Дослідити теоретичні засади реалізації міжпредметної інтеграції в освітньому процесі початкової школи.

2. Обгрунтувати моделі предметно-інтегрованого навчання в початковій школі.

3. Висвітлити особливості проведення науково-методичних заходів для педагогічних працівників - учасників дослідно-експериментальної роботи регіонального рівня.

У статті репрезентовано результати дослідно-експериментальної роботи регіонального рівня. Уперше запропоновано моделі предметно-інтегрованого навчання молодших школярів у закладах загальної середньої освіти різних типів, різних організаційних та змістових умов. Подальшого розвитку набули ідеї застосування інтегрованого навчання молодших школярів.

Виклад основного матеріалу 3 обгрунтуванням отриманих наукових результатів.

Науково-теоретичною основою добору змісту початкової освіти, визначення теоретико-методологічних засад організації освітнього процесу в початкові школі на засадах міжпредметної інтеграції є концептуальні ідеї гуманістичної парадигми освіти, реалізація діяльнісного підходу, закономірності формування особистості та розвитку молодшого школяра, ідеї використання міжпредметних зв'язків та предметно-інтегрованого навчання.

Кафедра теорії й методики дошкільної та початкової освіти Миколаївського обласного інституту післядипломної педагогічної освіти з 2017 року проводить дослідно-експериментальну роботу регіонального рівня за темою «Упровадження технології інтегрованого навчання в початковій школі на засадах ідей та положень
Нової української школи» на базі МОІППО та закладів освіти області.

Розвивально-формувальний етап експерименту триває з 2018 до 2021 року. Його завдання - дослідження особливостей, побудова моделей та розроблення навчально-методичного комплексу щодо впровадження технології інтегрованого навчання молодших школярів як провідної в початковій школі, у закладах загальної середньої освіти різних типів, різних організаційних та змістових умовах.

Реалізацію програми дослідно-експериментальної роботи на цьому етапі забезпечено таким науково-методичним супроводом: консультаціями, робочими зустрічами, майстер-класами, вебінарами, науково-методичними рекомендаціями. Обмін досвідом учителів-експериментаторів здійснюється в рамках діяльності дослідницької науково-методичної лабораторії «Компетентнісно орієнтоване навчання школярів у інтегрованому середовищі засобами проєктно-ігрової діяльності».

На цьому етапі побудовано й апробовано чотири моделі предметно-інтегрованого навчання в початковій школі на засадах ідей та положень Нової української школи.

Модель 1. Організація освітнього процесу в умовах одночасної роботи учнів двох малочисельних класів із максимальним використанням засобів інтеграції.

Модель 2. Використання системи скорочених уроків із почерговим залученням учнів різних класів до спільної робоmu.

Апробація зазначених моделей здійснювалася на базі експериментальних закладів освіти - Першотравневої філії Новобузької загальноосвітньої школи I-III ступенів № 1 Новобузької районної ради та Бандурського навчально-виховного комплексу «дошкільний навчальний заклад - загальноосвітній навчальний заклад I-III ступенів» Первомайської районної ради Миколаївської області.

Ураховуючи поступове впроваджен- 
ня нового Державного стандарту початкової освіти у 2019-2020 навчальному році, перевагу надано використанню системи скорочених уроків (модель 2), що передбачає проведення по два окремі уроки для кожного з класів комплекту та два, переважно однопредметні, що передбачають організацію одночасної роботи учнів двох малочисельних класів із максимальним використанням засобів інтеграції.

Ефективність освітнього процесу в експериментальних класах визначено через взаємодію і взаємозв'язок відповідних організаційних і психолого-дидактичних умов організації освітнього процесу в класі-комплекті.

Визначено і створено такі організаційні умови: доцільне поєднання класів у комплекти; відповідна побудова розкладу уроків; календарне планування вивчення навчального матеріалу на засадах інтеграції; створення розвивального освітнього середовища; професійна компетентність учителя; реалізація принципів педагогіки партнерства в освітньому процесі.

В експериментальних класах-комплектах реалізовано такі психолого-дидактичні умови організації освітнього процесу: застосування оптимальної структури й змісту уроків на засадах інтеграції та компетентнісного підходу відповідно до рівня розвитку учнів та очікуваних освітніх результатів; упровадження кооперативного навчання, формування у здобувачів освіти навичок навчального співробітництва, самостійності й активності в процесі пізнання; вибір оптимального поєднання методів і прийомів навчання на окремих уроках інтегрованого змісту з малочисельним колективом учнів та проведення інтегрованих однопредметних та різнопредметних уроків в умовах зведення.

Педагогічні працівники, які працюють в умовах класу-комплекту, підготовлені до експериментальної роботи через залучення до участі в науково-методичних заходах на базі експериментальних класів.

Під час засідання науково-методич- ної лабораторії для вчителів початкової освіти «Формування наскрізних умінь у молодших школярів на засадах інтегрованого навчання» та робочих зустрічей учителів пілотних класів презентовано моделі упровадження інтегрованого навчання в початковій школі. Стали традиційними консультативні наставницькі візити в експериментальні заклади освіти. Результатом роботи $є$ розроблення стратегії інтегрованого підходу до вивчення української мови та літературного читання в умовах класу-комплекту, представлено засоби апробації посібника В. І. Шуляра «Абетка літературознавства» в інтегрованому просторі мовно-літературної освіти молодших школярів сільської малокомплектної школи.

У ході дослідно-експериментальної роботи здійснюється підготовка педагогічних працівників, які працюють в умовах класу-комплекту, як на курсах підвищення кваліфікації, так і через постійну участь у науково-методичних заходах на базі пілотних класів опорної Новобузької ЗОШ I-III ступенів Новобузької районної ради.

17 квітня 2019 року на базі Миколаївської обласної санаторної школиінтернату I-III ступенів № 7 Миколаївської обласної ради проведено засідання науково-методичної лабораторії для вчителів початкової школи «Формування наскрізних умінь у молодших школярів на засадах інтегрованого навчання». 22 листопада 2019 року вчителі Першотравневої філії стали учасниками робочої зустрічі вчителів пілотних класів, яку проведено на базі Вознесенської ЗОШ I-III ступенів № 8 Вознесенської міської ради.

Мета проведених заходів: презентація моделей упровадження інтегрованого навчання в початковій школі на засадах ідей та положень Нової української школи. Результати роботи: представлено стратегію апробації посібника В. І. Шуляра «Абетка літературознавства» в інтегрованому просторі мовно-літературної освіти молодших школярів. 
14 листопада 2019 року 3 метою реалізації засад Концепції «Нова українська школа» на базі Новоодеської ЗОШ I-III ступенів № 3 Новоодеської районної ради проведено університет знань методистів початкової освіти науково-методичних установ та керівників шкільних методичних об'єднань інтернатних закладів обласного підпорядкування 3 проблеми «Використання евристичних методів навчання на уроках у початковій школі та методичній роботі з педагогічними кадрами» спільно $з$ учасниками науково-методичної лабораторії з питань розвитку початкової освіти «Упровадження технології предметно-інтегрованого навчання у початковій школі». Результати роботи: підвищення фахової майстерності та інноваційного розвитку методистів із початкової освіти науково-методичних установ, керівників методичних об'єднань учителів початкових класів області.

Учителі Першотравневої філії брали активну участь у засіданнях науково-методичної лабораторії 17 квітня 2019 року на тему «Формування наскрізних умінь у молодших школярів на засадах інтегрованого навчання», яку проведено на базі Миколаївської санаторної школи-інтернату I-III ступенів № 7 Миколаївської обласної ради та 14 листопада 2019 року на тему «Використання евристичних методів навчання в освітньому процесі Нової української школи» на базі Новоодеської ЗОШ I-III ступенів № 3 Новоодеської районної ради.

Модель 3. Упровадження інтегрованого навчання молодших школярів на засадах ідей та положень Концепції «Нова украӥнська школа» в умовах закладу загальної середньої освіти.

Апробація зазначеної моделі відбувається на базі Миколаївської загальноосвітньої школи I-III ступенів № 56 Миколаївської міської ради.

Ефективність роботи в окресленому напрямі визначають:

1) добір форм та методів роботи, які підвищують ефективність форму- вання ключових компетентностей, розвивають творчу активність;

2) опанування учнями ключових компетентностей, необхідних для організації власного навчального середовища, отримання нової інформації з метою застосування іii для навчальних та життєвих потреб;

3) навички партнерської взаємодії, орієнтовані на розвиток і формування людини - духовно, інтелектуально, психологічно підготовленої до самостійного життя.

Рекомендовані форми організації освітнього процесу - дослідницькі, інформаційні, мистецькі проєкти, сюжетно-рольові ігри, інсценізації, моделювання, ситуаційні вправи, екскурсії, дитяче волонтерство тощо. На основі Типової програми можливі засоби інтеграції передбачають включення учнів в практику формування наукового мислення та культури дослідження, виконання різноманітних завдань дослідницького характеру, а саме: дослідження-розпізнавання, порівняння з іншими предметами, явищами; дослідження-спостереження, дослідження-пошук - установлення причинно-наслідкових зв'язків.

У ході дослідно-експериментальної роботи відбулися консультативні візити до Миколаївської загальноосвітньої школи I-III ступенів № 56 Миколаївської міської ради Миколаївської області. 06 грудня 2017 року проведено ранкову зустріч на тему «Як живуть комахи. Бджола-трудівниця» та урок навчання грамоти (читання) на тему «Закріплення звукового значення букви «ер». Читання слів, анаграм, побудова речень за малюнками. Опрацювання оповідання за П. Костюченком». 01 лютого 2018 року організовано та проведено дослідницько-проєктну діяльність на тему: «Комахи в житті людини», яку розпочато ранковою зустріччю та продовжено на уроці природознавства. 18 квітня 2018 року проведена творча зустріч, учасники якої спостерігали за виконанням про- 
єкту на тему «Чи важливо дотримуватися правил руху для пішоходів?». Розпочато дослідницьку діяльність ранковою зустріччю на тему «Я - пішохід». Продовжив хід проєкту інтегрований урок математики та основ здоров'я в першому класі на тему «Розкладання двоцифрових чисел на розрядні доданки. Додавання та віднімання двоцифрових чисел, пов'язаних із нумерацією. Складання та розв'язування задач за малюнками здоров'язбережувального характеру. Креслення відрізків». Завершення проєкту відбулося на уроці «Я досліджую світ», де визначено життєву важливість теми та проведено тренінг щодо безпечної поведінки на дорозі.

Модель упровадження інтегрованого навчання молодших школярів презентована 28 лютого 2020 року на робочій зустрічі учасників регіонального експерименту 3 питань розвитку початкової освіти «Упровадження технології інтегрованого навчання в початковій школі на засадах ідей та положень Нової української школи на базі МОІППО та закладів загальної середньої освіти області», проведеній на базі Миколаївської загальноосвітньої школи I-II ступенів № 64 Миколаївської міської ради.

Педагоги зазначили такі ознаки цінності методу проєктів:

1) учні навчаються добре виконувати навчальну роботу, відчуваючи при цьому радість та гордість за свої результати;

2) в учнів формується позитивне ставлення до своєї школи;

3) діти навчаються мислити, оперуючи фактами, а не передбаченнями;

4) учні навчаються вчитися, знають, як потрібно шукати матеріал, розуміти факти, обгрунтовувати їх;

5) набувають навичок роботи в дитячому колективі, зважати на думку інших;

6) школярі вчаться аналізувати, шукати шляхи вирішення проблем, підсумовувати виконане завдання.

Представлено також напрацювання 3 досвіду роботи педагогів - збірник «Скарбничка ідей. Ранкові зустрічі».

Модель 4. Упровадження інтегрованої технології в умовах інклюзивного навчання у початковій школі повного дня на засадах ідей та положень Нової української школи.

Базовими експериментальними майданчиками для апробації моделі стали Миколаївський спеціальний навчально-виховний комплекс для дітей зі зниженим зором Миколаївської міської ради та Миколаївська загальноосвітня санаторна школа-інтернат I-III ступенів № 7 Миколаївської обласної ради.

Інклюзія та інтеграція - провідні тенденції сучасного етапу розвитку системи освіти України. Кожна дитина, незалежно від своїх особливостей - фізичних, інтелектуальних, соціальних, емоційних чи мовних, повинна здобути якісну освіту.

Ефективність роботи окресленого напряму визначають:

1) урахування особливостей організації освітнього процесу у початковій школі повного дня;

2) можливість використовувати інтегроване навчання, проєктно-дослідницьку діяльність як гнучку модель організації освітнього процесу, орієнтовану на творчу самореалізацію особистості;

3) розвиток можливостей особистості у процесі створення нового продукту під контролем учителя через самостійну, колективну, інтерактивну діяльність та обов'язкову презентацію результатів роботи;

4) ефективність занять підвищується, коли вони проводяться не тільки у класі, а й в інших приміщеннях: у бібліотеці, музично-спортивному залі, на подвір'ї;

5) умови спеціальних закладів загальної середньої освіти дозволяють співвідносити інтегроване навчання з роботою в другій половині дня. 
Проведення тематичних днів та тижнів продовжується організацією музичних і родинних свят, роботою гуртків і секцій, фізкультурними заходами в групі продовженого дня.

Проведення дослідницької роботи відбувається у процесі ігрової діяльності, спілкуванні з довкіллям:

1) особлива увага надається залученню всіх органів чуття до сприймання матеріалу, мовній складовій із використанням наочності, аудіо- та відеоматеріалів, що дає можливість учням цілісно обстежити предмет чи отримати повне уявлення про явище;

2) до проведення інтегрованого навчання залучаються вчителі-предметники, які викладають у початкових класах англійську мову, образотворче та музичне мистецтво, інформатику;

3) підпорядковані цьому і заняття корекційного курсу (розвиток мовлення, корекція розвитку, соціально-побутове орієнтування).

Представлена модель «Упровадження інтегративної технології в умовах інклюзивного навчання у початковій школі повного дня» 14 листопада 2019 року на засіданні науково-методичної лаборатоpiї 3 питань розвитку початкової освіти «Упровадження технології предметно-інтегрованого навчання в початковій школі», проведеної на базі Новоодеської ЗОШ I-III ступенів № 3 Новоодеської районної ради. Також учителі представили стратегію апробації посібника В. І. Шуляра «Абетка літературознавства» в інтегрованому просторі мовно-літературної освіти молодших школярів.

Згідно $з$ програмою дослідно-експериментальної роботи в указаних закладах загальної середньої освіти проведено низку заходів.

29 листопада 2017 року відбувся консультативнийвізитуМиколаївськузагальноосвітню санаторну школу-інтернат I-III сту- пенів № 7 Миколаївської обласної ради. Цього дня проведено ранкові зустрічі у перших класах на тему «Безпечний шлях до школи» та уроки навчання грамоти (читання) на тему «Звук [п], позначення його буквами Пп. Словниково-логічні вправи. Робота над текстом «На Івана Купала» та основ здоров'я на тему «Фізичні вправи та загартовування».

12 грудня 2017 року - консультативний візит у Миколаївський спеціальний навчально-виховний комплекс для дітей зі зниженим зором Миколаївської міської ради Миколаївської області. Проведено проєктну діяльність на тему «Україна космічна», яку розпочала ранкова зустріч та інтегрований урок навчання грамоти (читання) на тему «Звуки [3], [3’]. Буква «зе». Відпрацювання дзвінкої вимови. Заучування скоромовок, фразеологізмів».

25 січня 2018 року здійснено консультативний візит у Миколаївську загальноосвітню санаторну школу-інтернат I-III ступенів № 7 Миколаївської обласної ради. Здійснений проєкт на тему «Мандруємо Україною», розпочатий на ранковій зустрічі та продовжений на уроці основ здоров'я темою «Активний і пасивний відпочинок».

20 лютого 2018 року відбувся консультативний візит у Миколаївський спеціальний навчально-виховний комплекс для дітей зі зниженим зором Миколаївської міської ради. Проведений мініпроєкт на тему «Книга в житті людини», представлений на ранковій зустрічі та продовжений на уроці навчання грамоти (читання) на тему «Закріплення звукового значення букви «же». Опрацювання уривка казки «Лисичка і Журавель». Прислів’я. Робота 3 дитячою книжкою».

25 квітня 2018 року проведено творчу зустріч на базі Миколаївськоїзагальноосвітньої санаторної школи-інтернату I-III ступенів № 7 Миколаївської обласної ради. Учасники заходу відвідали ранкову зустріч на тему «Сімейні традиції родини» та інтегрований урок основ здоров'я та української мови в першому класі на тему «Тра- 
диції збереження здоров'я в родині».

7 квітня 2019 року на базі Миколаївської обласної санаторної школи-інтернату I-III ступенів № 7 Миколаївської обласної ради проведено засідання науково-методичної лабораторії для вчителів початкової освіти «Формування наскрізних умінь у молодших школярів на засадах інтегрованого навчання». Проведено уроки із використанням посібника В. І. Шуляра «Абетка літературознавства» «Друга легше знайти, ніж зберегти. Василь Сухомлинський «Кінь утік».

9 квітня 2020 року проведено в асинхронному режимі творчу онлайн-зустріч учасників регіонального експерименту «Упровадження технології інтегрованого навчання в початковій школі на засадах ідей та положень Нової української школи на базі МОІППО та закладів загальної середньої освіти області» у рамках творчої лабораторії обласного рівня «Формування компетентностей здобувачів освіти засобами інтеграції».

Підсумовуючи проведення регіонального експерименту на базі закладів загальної середньої освіти, у яких є школа I ступеня, «Упровадження технології інтегрованого навчання в початковій школі на засадах ідей та положень Нової української школи», 20 листопада 2020 року в онлайн-режимі проведено робочу зустріч «Діяльнісний підхід у формуванні наскрізних умінь учнів початкової школи засобами математичної освітньої галузі». Учителі-експериментатори представили досвід роботи із зазначеної теми, поділилися своїми напрацюваннями. За час проведення регіонального експерименту визначено моделі впровадження інтегрованого навчання, проведено відкриті уроки, майстер-класи, удосконалено освітнє середовище. Учителям запропоновано укласти навчально-методичний комплекс для вчителів початкових класів щодо упровадження інтегрованого навчання молодших школярів на засадах ідей та положень Нової української школи.
Висновки та перспективи подальшого дослідження проблеми.

Проведена дослідно-експериментальна робота дозволила дійти таких висновків.

Інтеграція багатокомпонентного змісту початкової освіти та форм організації освітнього процесу сприяє формуванню міцних, усвідомлених міжпредметних зв'язків, формуванню цілісної картини світу, наукового світогляду.

У статті досліджено теоретичні засади реалізації міжпредметної інтеграції в освітньому процесі початкової школи. Здійснено аналіз основних досліджень і публікацій із зазначеної проблеми. Теоретичними засадами реалізації міжпредметної інтеграції в освітньому процесі початкової школи, що стали науково-теоретичною основою добору змісту початкової освіти та визначили теоретико-методологічне підгрунтя організації освітнього процесу в екпериментальних класах, $є$ концептуальні ідеї гуманістичної парадигми освіти, реалізація діяльнісного підходу, закономірності формування особистості та розвитку молодшого школяра, ідеї використання міжпредметних зв'язків та предметно-інтегрованого навчання.

У процесі реалізації програми дослідно-експериментальної роботи регіонального рівня «Упровадження технології інтегрованого навчання в початковій школі на засадах ідей та положень Нової української школи» обгрунтовано й апробовано чотири моделі упровадження інтегрованого навчання в початковій школі.

Модель 1. Організація освітнього процесу в умовах одночасної роботи учнів двох малочисельних класів із максимальним використанням засобів інтеграції.

Модель 2. Використання системи скорочених уроків із почерговим залученням учнів різних класів до спільної роботи.

Модель 3. Упровадження інтегрованого навчання молодших школярів на засадах ідей та положень Концепції «Нова українська школа» в умовах закладу загальної середньої освіти. 
Модель 4. Упровадження інтегрованої технології в умовах інклюзивного навчання у початковій школі повного дня на засадах ідей та положень Нової української школи.

Програмою дослідно-експериментальної роботи передбачено проведення науково-методичних заходів для педагогічних працівників-учасників. Науково-методичний супровід здійснювався через проведення консультацій, робочих зустрічей, майстер-класів, вебінарів, надання науково-методичних рекомендацій. Обмін досвідом учителів-експериментаторів здійснюється в рамках діяльності дослідницької науково-методичної лабораторії «Компетентнісно орієнтоване навчання школярів у інтегрованому середовищі засобами проєктно-ігрової діяльності». Учителі-експериментатори представляли досвід роботи iз зазначеної теми, ділилися своїми напрацюваннями. Окреслена діяльність сприяла підвищенню професійної компетентності вчителів-експериментаторів.

Проведена дослідницька робота остаточно не вирішує проблему застосування технології предметно-інтегрованого навчання в освітньому процесі початкової школи. Перспективним напрямом уважаємо розроблення змістового наповнення моделей упровадження інтегрованого навчання молодших школярів на засадах ідей та положень Концепції «Нова українська школа» у початковій школі.

\section{ЛІТЕРАТУРА}

1. Большакова I. О. Особливості реалізації міжпредметної інтеграції змісту навчання на уроках у початковій школі [Електронний ресурс] / I. О. Большакова. - 2015. - Режим доступу до ресурсу: https://cutt.ly/0gVwoiW

2. Державний стандарт початкової освіти. [Електронний ресурс]. - 2019. - Режим доступу до ресурсу: https://zakon.rada.gov.ua/laws/show/87-2018-\%D0\%BF

3. Інтегроване навчання - Глосарій. Онлайн-курс для вчителів початкових класів. [Електронний ресурс]. - 2017. - Режим доступу до ресурсу: https://edera.gitbook.io/ glossary/integraciya/intehrovane_navchannia

4. Інтегроване навчання: тематичний і діяльнісний підходи. [Електронний ресурс]. - 2017. - Режим доступу до ресурсу: https://nus.org.ua/articles/integrovane-navchannyatematychnyj-i-diyalnisnyj-pidhody-chastyna-2/

5. Концепція «Нова українська школа». [Електронний ресурс]. - 2016. - Режим доступу до ресурсу: https://mon.gov.ua/storage/app/media/zagalna\%20serednya/novaukrainska-shkola-compressed.pdf

6. Мариновська О. Я. Інтегральна технологія навчання: від теорії до практики. / О. Я. Мариновська. // Початкова освіта. - 2011. - № 32 (608). - С. 3-5.

7. Навчальні програми для 1-4 класів. [Електронний ресурс]. - 2017. - Режим доступу до ресурсу: https://mon.gov.ua/ua/osvita/zagalna-serednya-osvita/navchalni-programi/ navchalni-programi-dlya-pochatkovoyi-shkoli

8. Ніколенко Л. Т. Нова українська школа: інтеграційний підхід у початковій загальній освіті / Л. Т. Ніколенко. - Київ : Шкільний світ. Київська правда, 2012. - (Київська правда).

9. Ніколенко Л. Т. Нова українська школа: інтеграційний підхід у початковій загальній освіті / Л. Т. Ніколенко. // Початкова освіта. - 2018. - № 12. - С. 5-7.

10. Нова українська школа: порадник для вчителя / за ред. Н. Б. Бібік. - Київ : Літера ЛТД, 2018. - 160 с.

11. Письменна I. I. Імплементація зарубіжного досвіду щодо використання принципів інтегрованого навчання у вищій школі / I. I. Письменна. // Вісник університету імені Альфреда Нобеля. Серія «Педагогіка і психологія». Педагогічні науки. - 2019. № 1 (17). - C. 169-175. DOI: 10.32342/2522-4115-2019-1-17-21. 


\title{
АПРОБАЦИЯ МОДЕЛЕЙ ВНЕДРЕНИЯ ИНТЕГРИРОВАННОГО ОБУЧЕНИЯ В НАЧАЛЬНОЙ ШКОЛЕ: ДОСТИЖЕНИЯ ОПЫТНО-ЭКСПЕРИМЕНТАЛЬНОЙ РАБОТЫ РЕГИОНАЛЬНОГО УРОВНЯ
}

\author{
Сокуренко Елена, \\ кандидат педагогических наук, доиент, \\ заведующая кафедрой теории и методики \\ дошкольного и начального образования \\ Николаевский областной институт \\ последипломного педагогического образования \\ ул. Адмиральская, 4-а, 54001, г. Николаев, Украина \\ olena.sokurenko@moippo.mk.ua \\ Рыбачук Оксана, \\ методист кафедры теории и методики \\ дошкольного и начального образования \\ Николаевский областной институт \\ последипломного педагогического образования \\ ул. Адмиральская, 4-а, 54001, г. Николаев, Украина \\ oksana.rybachuk@moippo.mk.ua
}

В Концеепции «Новая украинская школа» определень стратегические задачи реформирования системь образования Украинь. Это обусловливает иелесообразность реализачии компетентностного подхода в начальной школе средствами интеграчии содержания образования и форм организачии образовательного процесса. Такой подход требует исследования региональных особенностей организации образовательного процесса в начальной школе. В статье представлены результаты опытно-экспериментальной работы регионального уровня по теме «Внедрение технологии интегрированного обучения в начальной школе на основе идей и положений Новой украинской школьы» на базе НОИППО и учебных заведений области, которую проводит кафедра теории и методики дошкольного и начального образования Николаевского областного института последипломного педагогического образования. Такая деятельность направлена на разработку и апробацию моделей внедрения интегрированного обучения младщих школьников на основе идей и положений Новой украинской школы для различных типов учебных заведений, в которых есть школа I степени.

Ключевые слова: интеграчия; интегрированное обучение; компетентностный подход; межпредметные компетентности; модели интегрированного обучения; начальная школа; новая украинская школа; образовательный процесс.

\section{APPROBATION OF INTEGRATED LEARNING MODELS IN PRIMARY SCHOOL: ACHIEVEMENTS OF EXPERIMENTAL WORK AT THE REGIONAL LEVEL}

\author{
Sokurenko Olena, \\ Candidate of Pedagogical Sciences (Ph.D.), \\ Associate Professor, \\ Head of Department of Theory and Methods of \\ Preschool and Primary Education \\ Mykolaiv In-Service Teachers Training Institute \\ 4-a Admiralska Street, 54001, Mykolaiv, Ukraine \\ olena.sokurenko@moippo.mk.ua
}




\section{Rybachuk Oksana, educator \\ Department of Theory and Methodology of Preschool and Primary Education Mykolaiv In-Service Teachers Training Institute 4-a Admiralska Street, 54001, Mykolaiv, Ukraine oksana.rybachuk@moippo.mk.ua}

The Concept of the New Ukrainian School defines the strategic objectives to reform the education system of Ukraine. It determines the implementation of a competency-based approach in primary school by integrating the content and forms of the learning process. The relevance of the use of interdisciplinary integration is confirmed by the State Standard of Primary Education.

The integrated approach in primary school makes it possible to form students 'qualitatively different knowledge, characterized by a higher level of cognitive processes, thinking skills, and the ability to apply them in new situations.

This approach requires a study of local features of the learning process management in primary school. The article presents the results of research and experimental work at the regional level on "Integrated learning technology in primary school within the ideas and provisions of the New Ukrainian School» in cooperation with Mykolaiv In-Service Teachers Training Institute and local schools. The project was charged by the Department of Theory and Methods of Preschool and Primary Education postgraduate pedagogical education.

Keywords: competence approach; educational process; integrated learning; integration; interdisciplinary competencies; models of integrated learning; new Ukrainian schoolprimary school.

\section{REFERENCES}

1. Bibik, N. B. (Ed.). (2018). Nova ukrainska shkola: poradnyk dlia vchytelia [New Ukrainian school: a guide for teachers]. Kyiv: Litera LTD (ukr).

2. Bolshakova, I. O. (2015). Osoblyvosti realizatsii mizhpredmetnoi intehratsii zmistu navchannia na urokakh u pochatkovii shkoli. [Elektronnyi resurs]. [Peculiarities of realization of interdisciplinary integration of the content of training at lessons in elementary school]. Retrieved from: https://cutt.ly/0gVwoiW (ukr).

3. Intehrovane navchannia - Hlosarii. Onlain-kurs dlia vchyteliv pochatkovykh klasiv. (2017). (Elektronnyi resurs). [Integrated learning - Glossary. An online course for primary school teachers]. Retrieved from: https://edera.gitbook.io/glossary/integraciya/intehrovane_ navchannia (ukr).

4. Intehrovane navchannia: tematychnyi i diialnisnyi pidkhody. (2017). (Elektronnyi resurs). [Integrated learning: thematic and activity approaches]. Retrieved from: https://nus. org.ua/articles/integrovane-navchannya-tematychnyj-i-diyalnisnyj-pidhody-chastyna-2/ (ukr).

5. Kontseptsiia «Nova ukrainska shkola». (2016). (Elektronnyi resurs). [The concept of the «New Ukrainian School»]. Retrieved from: https://mon.gov.ua/storage/app/media/zagalna\%20 serednya/nova-ukrainska-shkola-compressed.pdf (ukr).

6. Marynovska, O. Ya. (2011). Intehralna tekhnolohiia navchannia: vid teorii do praktyky [Integral learning technology: from theory to practice]. Pochatkova osvita, 32 (608), 3-5 (ukr).

7. Navchalni prohramy dlia 1-4 klasiv. (2017). [Elektronnyi resurs]. [Curricula for grades 1-4]. Retrieved from: https://mon.gov.ua/ua/osvita/zagalna-serednya-osvita/navchalni- 
programi/navchalni-programi-dlya-pochatkovoyi-shkoli (ukr).

8. Nikolenko, L. T. (2012). Nova ukrainska shkola: intehratsiinyi pidkhid u pochatkovii zahalnii osviti. [New Ukrainian school: integration approach in primary general education]. Kyivska pravda. Kyiv: Shkilnyi svit (ukr).

9. Nikolenko, L. T. (2018). Nova ukrainska shkola: intehratsiinyi pidkhid u pochatkovii zahalnii osviti. [New Ukrainian school: integration approach in primary general education]. Pochatkova osvita, 12, 5-7 (ukr).

10. Pysmenna, I. I. (2019). Implementatsiia zarubizhnoho dosvidu shchodo vykorystannia pryntsypiv intehrovanoho navchannia u vyshchii shkoli. [Implementation of foreign experience in the use of the principles of integrated education in higher education]. Visnyk universytetu imeni Alfreda Nobelia. Seriia «Pedahohika i psykholohiia». Pedahohichni nauky, 1 (17), 169175, DOI: 10.32342/2522-4115-2019-1-17-21 (ukr).

11. State standard of primary education. (2019). Retrieved from: https://zakon.rada.gov. ua/laws/show/87-2018-\%D0\%BF (ukr). 